\title{
Study on Accounting Treatment of the Third Party Payment Platform
}

\author{
He Shuhong \\ School of Management, Xi'an University of Science and \\ Technology \\ Xi'an, Shaanxi, 710054
}

\author{
Yang Lihong \\ School of Management, Xi'an University of Science and \\ Technology \\ Xi'an, Shaanxi, 710054
}

\begin{abstract}
This paper analyzes the accounting treatment environment and major accounting thinking of the third-party payment system on the basis of the operation model of China' $s$ third-party payment platform. Besides, problems that the Chinese accounting information quality is easy to be threatened, accounting software and personnel are difficult to adapt to the new environment changes as well as the imperfect related laws on the accounting treatment and slow development of accounting internalization have been discovered through the way of inductive analysis on this basis. According to these problems, this paper has proposed the corresponding countermeasures and suggestions in combination with the previous research achievements and the current conditions of China.
\end{abstract}

Keywords-The Third Payment Platform; Accounting Treatment; Countermeasures

\section{INTRODUCTION}

The third party payment platform is a "central platform" that provides funds for trading activity, and it can let consumers, financial institutions and merchants realize payment, cash flow, settlement, balance inquiry through advanced communication and computer technology to combine different trading parties together. At the same time, it can provide more diversified payment methods and reliable service security for consumers, and let E-business trading be more diversified and simpler.

\section{ANALYSIS OF BUSINESS MODE}

Next analysis will be made to the business mode of the third party payment platform taking Alipay and TenPay as examples:

In the process of E-business trading, the third party payment platform usually provides exclusive virtual account for each customer. The account is the carrier of cash flow in the system, and users can make use of the account to conduct operations such as information inquiry, recharging, transferring and cash deposit according to instructions after registration [1].

(1) After deciding the product to buy in E-business website, the buyer will select payment method and transfer the payment to the account of the third party platform.

(2) After receiving the order of buyers, the third party platform will inform the seller that the payment has been transferred to the account of the third party platform, and ask the seller to deliver goods to the buyer in regular time.

(3) After receiving payment notice, the seller will make corresponding record and deliver goods according to the order of buyer. During this period, the consumer can check the shipping status through purchasing record in the website. If the seller fails to ship and deliver in regulated time, the third party platform will inform the buyer that the trade is failure, and the buyer can select to continue to deposit the payment in the third party payment platform or transfer to their own bank account.

(4) When the goods are delivered, and the buyer can notice the third party confirms if they are satisfied with the goods and confirm to receive them; while they are unsatisfied with the goods, they can negotiate with the seller to return the goods, and notice the third payment platform to refuse to pay for the seller.

(5) If the buyer notice the third payment platform that he has received the goods and he is satisfied with the goods, the third party will transfer the payment to the account of the seller; If the buyer is not satisfied with the goods he bought, the third party platform can return the payment of the goods to the account of the consumer after receiving the information that the buyer confirms to return the goods, or consumers can select to deposit the payment in the third party platform voluntarily for the convenience of the next shopping.

The third party payment platform plays an important role in the whole trading system, and it doesn't only combine the buyer and the seller together, and compose a stable payment system, but also provides a more convenient platform and environment for the trading activity of both the parties.

\section{ANALYSIS OF THE ACCOUNTING ENVIRONMENT}

In recent years, the rapid development of computer technology lets our country enter E-commerce Age, while the accounting environment that the third party payment system is in is also changing constantly under such historical background. The most representative feature is the emerging of multitrading method, because the information technology that is matured gradually lets more and more enterprises have wider vision, and they intend to invest in internationalized internet market, so many enterprises try to open new investment channel, and create diversified payment methods, such as Ebank payment, Alipay, and Wechat that is very popular 
currently, etc.; At the same time, forms of traditional real enterprises are affected [2]. In the environment of high-tech development that develops rapidly, new-style organizing forms of virtue enterprises will be the subject in the future. More and more virtue enterprises emerge in China market constantly, which will change the structure of traditional enterprises constantly. In addition, investment subjects of enterprises are also changed. In the past, investors of enterprises paid more attention to investment of funds and substantial, while in current era of information economy, investment of intangible assets such as knowledge and information are more important, and more and more enterprises stress communication and spreading of information; At present, economic globalization is also one of the features displayed by accounting environment, and the intervening of E-business lets the past accounting treatment not be able to satisfy the market requirement. And communication and negotiation of E-business among countries become closer and closer. In order to comply with the change of the market, the accounting environment of the third party payment platform at present needs to march towards informatization and globalization constantly [3]. The system of the third party payment platform in China started lately, and Chinese laws are not perfect in this aspect, and the accounting treatment also has many disadvantages, which is also the problems that the future third party payment platform needs to consider in the process of development.

\section{PRIMARY THOUGHT OF ACCOUNTING TREATMENT}

Next the respective thought of accounting treatment will be analyzed according to the trading activities occurring in different stages of the system of the third party payment system from three perspectives of the buyer, seller and the third party payment institute. Here it is based on the condition that both the buyer and the seller are enterprises.

When enterprises need to pay or transfer to a third party payment platform or merchants, they need to transfer the funds to a virtue account from their bank account. At this time, the subject of "deposit in virtue account—XX the third party payment platform" should be debit, and the subject of "bank deposit" should be credited [4].

In order to let buyers buy satisfactory goods, payment is not paid to buyer's enterprise directly, but transferred to the account of the third party payment platform by the account of the buyer. If the buyer's enterprise adopts the amount in the virtue accounting directly, "prepayment" shall be debit, while the subject of "deposit in virtue account-XX the third party payment company" shall be credited; if the buyer's enterprise pays through the bank account, "prepayment" shall be debit, and "bank deposit" shall be credited. At this time, the seller will deliver to customers, but ordinary sellers will provide a certain period of service of sales return and refund, so the seller's enterprise can't ensure whether goods that have been delivered can be returned, and whether the trade can be successful. Under such condition, as to seller's enterprise, the subject of "goods delivered" shall be debit, and the subject of "inventory goods" shall be credited. Finally, when the third party payment platform receives payment of the buyer, "bank deposit" shall be debit and the subject "payment shall be paidseller" shall be credited.
When buyer's enterprises are satisfied and confirm to receive the goods, the third party payment institute will receive the notice, and payment will be transferred from the bank account to the virtue account of the seller's enterprise. At this time, as to the buyer, subjects such as "inventory goods" and "tax payable-value added tax payable" shall be debit, and subject of "prepayment" shall be credited. Because the buyer's enterprise has received the goods, it instructs that the benefit belongs to the seller's enterprise, and the third party payment institute will transfer the payment to the virtue account or bank account of the seller. At this time, the seller should debit "deposit of virtue account-XX the third party payment platform" and credit subjects of "main business income" and "tax payable-value added tax payable". At the same time, cost shall be carried down, "main business cost" shall be debit, and the subject of "delivered goods" shall be credited. When the trade being completed, the third party payment institute will usually get a certain commission according to a certain ratio of the trading amount (it is deducted from trading amount generally speaking), and the seller will take it as the fees produced in the sales process, so the seller should debit "sales fee-commission", and credit the subject of "deposit of virtue account-XX the third party payment company".

\section{PROBLEMS EXISTED IN ACCOUNTING TREATMENT}

At present, the development of the third party payment platform in China has had great progress in the field of Ebusiness, and the current developing trend is good. But it started lately in China, and the accounting treatment is not perfected and matured sufficiently, so the following disadvantages need to be solved.

\section{A. Quality problem of accounting information}

Although the rapid development of the technology of computer network brings many opportunities for the development of E-business, it also provides many convenience for accounting treatment of the third party payment platform, but the network environment has openness, and much information and resources can be shared with network network users, so the quality of accounting information is easy to be threatened.

\section{B. Accounting software and personnel problem}

At present the software of financial accounting in China is researched based on manual accounting method, and it stresses the reflecting function of accounting treatment. It mainly conducts accounting treatment to routine trading activity. While the accounting treatment of the third party payment platform pays more attention to the function of supervision and management, which predicts that the treatment of accounting software will develop and improve to management type under the background of E-business [5]. In addition, the wide application of network technology requires more and more to comprehensive talents, and accounting personnel doesn't only need to master traditional foundation knowledge of accounting, but also combine with a certain computer technology and knowledge of network management. 


\section{Legal protection problem in China}

Relevant laws and regulations of the third party payment platform in China is not perfect, so it causes problems in many fields, for instance, legal loophole may let some merchants find opportunities in it and conduct cutthroat competition; Financial personnel can't develop accounting treatment work by concrete system; Financial management status of enterprise performs confusion, etc.

\section{Problems of Accounting Internationalization}

Economic globalization is the general trend in the world' s current economic development; China is also accelerating its internalization development under such conditions. E-commerce always has the characteristic of enabling the capital to flow worldwide within a short period of time; however as China' s third-party payment platform starts late, it is not perfect yet in various aspects; therefore, it still cannot adapt to this characteristic. In addition, the deepening economic globalization has also intensified the competitiveness of each enterprises, as a result, the Chinese enterprises have to invest more money to research and develop new technologies and products, so as to strengthen their competitiveness and win the favorable development prospects. Nevertheless, most of the enterprises in the Chinese E-commerce market still have no such powerful capital strength to undertake such large amount of investment to cope with the fierce internationalized competitions.

\section{IMPROVEMENT MEASUREMENTS}

\section{A. Strengthen the management of the quality of accounting information}

To manage the internal of the enterprise. To hold training and educational activities about safety knowledge of accounting information so as to enhance the safety treatment capacity of international financial personnel inside the enterprise; To conduct comprehensive supervision to accounting treatment work of financial personnel through arranging specific personnel or formulating perfect system to avoid damages caused by illegal operation of financial personnel to accounting information.

To manage from the external of the enterprise. To enhance the quality of accounting information through methods such as installing gateway of accounting information, strengthening safety precaution system; To help the third party payment platform to find safety loophole and systematic loophole timely in accounting treatment effectively through researching inspecting system that is adaptive to the enterprise, and to formulate effective treatment measures so as to exclude unfavorable factors that have potential threatens to the quality of accounting information.

\section{B. Develop optimized accounting software and cultivate comprehensive accounting talents}

To conduct multi-functional research and development to accounting software. Developers need to improve the traditional accounting software, and combine with the current latest computer network to develop new administrationoriented accounting treatment software [6]. In addition, intensify safety protection in software system so as to avoid the software to be invaded and attacked.

Cultivation of the comprehensive capacity of accounting talents. To intensify the training of applying capacity in many aspects including computer network technology, management system of modernized enterprise of accounting staff so as to enhance organizing working efficiency. At the same time, to conduct storage of human resources to excellent complex financial personnel to let the enterprise have good and longterm development vision.

\section{Strengthen the legal construction of accounting}

The third party payment platform started lately in China, and the state still hasn't have perfect laws and regulations in this field. In order to solve the problems such as cutthroat competition brought by legal loophole, defects in the process of financial management and ensure the legal rights of public network trade, it seems very important to formulate corresponding legal countermeasures combining with the current national status of China. At present, China can formulate reasonable laws and regulations from aspects such as accounting criterion, operational system of the third party payment platform, and the fair trade of E-business so as to strengthen the security of the operational system of the third party payment, enhance the reliability of the accounting treatment of the third party payment platform so as to provide effective legal security for the economic development of Ebusiness in China.

\section{Accelerate the accounting internalization}

It is undeniable that E-commerce development is still considerably promising in the nowadays when the economic globalization is increasingly accelerated; what' s more, the accounting treatment of third-party payment platform will be more frequently focused on and discussed. To make China' s third-party payment system more internalized with more powerful competitiveness, the Chinese government shall provide certain policy support and capital investment for the third-party payment platform in addition to strengthening the accounting information quality, researching and developing the management-oriented software, cultivating the comprehensive talents as well as deepening and perfecting the laws and regulations. Moreover, China could also learn some experiences of accounting treatment from the foreign third-party payment institutions and flexibly formulate the development strategies that suitable to china' $\mathrm{s}$ E-commerce development according to the national conditions, so as to help China win the considerable development prospects in the international market. 


\section{CONCLUSION}

In recent years, with the development of computer network technology, the third party payment platform in China has made great progress, and transactions and business in different fields are increased gradually. However the accounting treatment of the third party payment platform in China is in budding stage, and there are still large defects in many aspects. Facing problems for instance the quality of accounting information is easy to be threatened, accounting software and personnel haven' $\mathrm{t}$ adapted to the new environment, the third party payment platform should strengthen management of the quality of accounting information, develop optimized accounting software, and cultivate comprehensive accounting personnel. It should be pointed out that at present relevant laws and regulations of the third party payment platform in China is not perfected sufficiently, so it is suggested that relevant departments should formulate feasible and effective administrative policies and regulations to enhance the reliability and security of accounting work of the third party payment institutes.

\section{REFERENCES}

[1] Mao Jinfen. Accounting Processing of the Business Mode of Alipay Under the Internet Financial Environment_-From the Perspective of the Third Party Payment Platform [J]. Finance and Accounting Monthly, 2016, (16):29-33.

[2] Chen Rutong. Provision Accounting of the Third Party Payment Platform: Taking Alipay as an Example [J]. Finance and Accounting Monthly, 2014, (8):45-48.

[3] Wang Xuehui, Ma Hongxiao. Study on Accounting Recognition of Ebusiness [J]. Finance and Accounting Communication, 2014, (31):23-24.

[4] Xiong Ranran. Discussion on Relevant Accounting Processing Problems of E-business Transaction based on the Third Party Payment Platform [J]. Assets and Finance of Administrative Affairs, 2015, (28):63-64.

[5] Deng Xiaolu. Discussion on Problems and Countermeasures Existed in Financial Accounting Under the Environment of E-business [J]. Financial Circle, 2013, (23):22-25.

[6] Sun Yuepan, Yang Chao, Liao Chen. Relevant Accounting Treatment Problems of the Third Party Payment Platform under the Environment of Internet Finance [J]. Finance and Accounting, 2014, (9):40-41. 